\title{
Evaluation of morphometric parameters and hypsometric curve of Arkavathy river basin using RS and GIS techniques
}

\author{
J. Harsha ${ }^{1,2}$ D $\cdot$ A. S. Ravikumar ${ }^{3}$ B. L. Shivakumar ${ }^{4}$
}

Received: 8 January 2019 / Accepted: 18 February 2020 / Published online: 4 March 2020

(c) The Author(s) 2020

\begin{abstract}
Water availability and water scarcity in a river basin are influenced by the geomorphological processes occurring within a river basin. Therefore, quantitative evaluation of the river basin shape provides a crucial lead in assessment of the impact of geomorphological processes on the hydrology of the basin. Arkavathy river basin has been selected for the present study. The basin with an annual average rainfall of $874.87 \mathrm{~mm}$ is a persistent water scarce basin located in Cauvery river basin in south India. The basin has been subjected to rapid urbanization due to which there is an increased water demand over a period of time. Hence, to tackle the growing water scarcity and reoccurrence of droughts in the basin, an attempt has been made in the present study to investigate and understand the basin morphometry and derivation of hypsometric curve of Arkavathy river basin using remote sensing (RS) and geographic information system (GIS) techniques. Quantitative evaluation of basin morphometry has been made, and the impact of basin morphometry on the peak runoff and flooding in the basin has been assessed. The basin hypsometric curve has aided in assessment of the erosion status of the basin and its impact on the risk of sedimentation on water bodies. The morphometric parameters and hypsometric curve are then analysed to investigate the potential impact of the basin morphometry on the water availability and water scarcity afflicting the basin.
\end{abstract}

Keywords Morphometry · Hypsometric curve · Drainage basin · Geomorphology · Hydrology

\section{Introduction}

Drainage or river basin, distinct with "divide" or "interfluves", is the fundamental landscape unit in which collection and distribution of water and sediment occur (Ritter 1995). According to Waikar and Nilawar (2014), the hydrological phenomena occurring in a drainage basin can

J. Harsha

infoharsha@yahoo.com

A. S. Ravikumar

profasrk68@gmail.com

B. L. Shivakumar

drshivakumarbl@gmail.com

1 Visvesvaraya Technological University, Belgaum, Karnataka, India

2 Central Water Commission, Government of India, Bengaluru, India

3 Department of Civil Engineering, UVCE, Bangalore University, Bengaluru, India

4 Department of Civil Engineering, MS Engineering College, Visvesvaraya Technological University, Bengaluru, India be correlated with its physiographic characteristics such as size, shape, slope, drainage density and stream density. Water scarcity and droughts in a river basin are caused due to increase in demand for water over a period of time as a consequence of increase in population, increased food production and energy, variation in rainfall pattern, climate change, etc. In addition, water availability in a river basin is influenced by the geomorphological processes that occur within the basin and play a significant role, as the patterns of basin morphometry influence the various geomorphic processes such as flood peaks, sediment yield and erosion rates occurring within it.

The quantitative evaluation of the basin and its land surface analysis also known as "morphometry" (Guth 2011) offer new insight into the hydrological process occurring within the basin and therefore serves as a crucial lead into the assessment of water scarcity in a river basin. Further, the geomorphic processes occurring within basins and landforms are analysed with the hypsometric curve of the basin which is the non-dimensional measure of the proportions of surface area of a catchment or watershed above a given elevation (Willgoose and Hancock 1998). Hypsometric curves 
assist in investigation of erosional stage of the basins and the lithology controlling the erosion in basin; and provide valuable information about the basin slope and geomorphology of the basin, which finds applications in watershed treatment, basin planning and identification of rainwater harvesting structures (Sarp et al. 2011).

Arkavathy river basin, located in the north-eastern part of Cauvery river basin in south India, faces persistent water shortage. The average annual rainfall of the basin found based on analysis of rainfall data from 1987 to 2014 is $874.87 \mathrm{~mm}$ (Table 1 ). The study area is located in agro-climatic zone, namely "Eastern Dry Zone" with a rainfall range of $679.1 \mathrm{~mm}$ to $888.9 \mathrm{~mm}$ (Department of Agriculture 2018). Rise in population is observed in the Arkavathy river basin in the past three decades particularly in the metropolitan city of Bengaluru wherein one-third

Table 1 Average annual rainfall (water year) in Arkavathy river basin

\begin{tabular}{|c|c|c|}
\hline Year & $\begin{array}{l}\text { Average rainfall in water year } \\
(\mathrm{mm})\end{array}$ & $\begin{array}{l}\text { Below or } \\
\text { above aver- } \\
\text { age }\end{array}$ \\
\hline 1987-1988 & 1038.92 & Above \\
\hline 1988-1989 & 786.04 & Below \\
\hline 1989-1990 & 747.73 & Below \\
\hline 1990-1991 & 531.18 & Below \\
\hline 1991-1992 & 1057.78 & Above \\
\hline 1992-1993 & 902.22 & Above \\
\hline 1993-1994 & 1008.77 & Above \\
\hline 1994-1995 & 653.59 & Below \\
\hline 1995-1996 & 757.73 & Below \\
\hline 1996-1997 & 1059.77 & Above \\
\hline 1997-1998 & 922.12 & Above \\
\hline 1998-1999 & 1195.30 & Above \\
\hline 1999-2000 & 937.98 & Above \\
\hline 2000-2001 & 1187.39 & Above \\
\hline 2001-2002 & 747.95 & Below \\
\hline 2002-2003 & 458.92 & Below \\
\hline 2003-2004 & 806.08 & Below \\
\hline 2004-2005 & 1003.11 & Above \\
\hline 2005-2006 & 1206.59 & Above \\
\hline 2006-2007 & 571.21 & Below \\
\hline 2007-2008 & 968.80 & Above \\
\hline 2008-2009 & 1078.21 & Above \\
\hline 2009-2010 & 896.13 & Above \\
\hline 2010-2011 & 1004.10 & Above \\
\hline 2011-2012 & 641.45 & Below \\
\hline 2012-2013 & 537.58 & Below \\
\hline 2013-2014 & 914.86 & Above \\
\hline
\end{tabular}

Average annual rainfall (water year) in Arkavathy river basin $=874.87 \mathrm{~mm}$

Source: Karnataka State Natural Disaster Monitoring Centre (KSNDMC), Government of Karnataka, Bengaluru, and author of the city is located in Arkavathy river basin. Bengaluru city and other cities continue to witness growth in terms of expanse and population. Though population and rainfall continue to influence the water supply and demand, the impact of geomorphological processes on hydrology of the Arkavathy river basin is very important in investigation of the causes of water scarcity that afflicts the basin.

Therefore, the objective/focus of the present study is derivation of morphological parameters and hypsometric curve for the Arkavathy river basin and, with morphometry and hypsometric curve, investigation of the potential impact on the water availability and water scarcity afflicting the basin.

\section{Study area}

Arkavathy river sub-basin is located within Cauvery river basin, southern India, and constitutes $5 \%$ of the area of Cauvery river basin (Fig. 1). Arkavathy river is a tributary of river Cauvery along with other rivers such as Shimsha, Hemavathy, Kabini, Bhavani, Noyyal and Amaravathy (Fig. 1). River Arkavathy originates at Nandi Hills located partly in Bangalore Rural district and partly in Chikkaballapur District in the north-eastern corner of the sub-basin and joins river Cauvery at Mekedatu, Kanakapura taluk, Ramanagar District (Figs. 2, 3). The total length of Arkavathy river across the longest drainage path is $165 \mathrm{~km}$, and the flow path is located entirely in the state of Karnataka. The total area of Cauvery river basin is $81,155 \mathrm{~km}^{2}$, whereas the area of Arkavathy river sub-basin is $4146.39 \mathrm{~km}^{2}$. Arkavathy river sub-basin within Cauvery river basin is located between co-ordinates $12^{\circ} 15^{\prime} 00^{\prime \prime} \mathrm{N}$ and $13^{\circ} 25^{\prime} 00^{\prime \prime} \mathrm{N}$ latitude and $77^{\circ} 10^{\prime} 00^{\prime \prime} \mathrm{E}$ and $77^{\circ} 45^{\prime} 00^{\prime \prime} \mathrm{E}$ longitude. About $97 \%$ of the sub-basin is located in the Karnataka State, whereas only 3\% is located in Tamil Nadu State. It spans across 3 districts of Karnataka, namely Ramanagara, Bangalore Rural and Bangalore Urban besides Krishnagiri District of Tamil Nadu (Fig. 3).

\section{Data products}

1. Digital elevation model (DEM) of NASA's Shuttle Radar Topography Mission (SRTM) available with Consortium of Space Information (CSI) of CGIAR, i.e. CSI-CGIAR (2018). From this DEM, the portion of Arkavathy basin was extracted in ArcGIS 10.2.

2. Survey of India (SoI) toposheets of 1:50,000 scale.

3. Lithology in Arkavathy river basin derived from the data of Central Ground Water Board (CGWB 2012). 
Fig. 1 Location map of Cauvery river basin and Arkavathy subbasin along with DEM of South India (DEM resolution $90 \mathrm{~m}$ at equator)

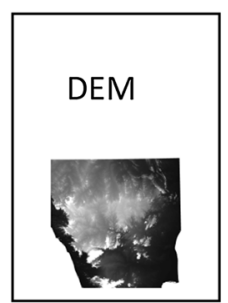

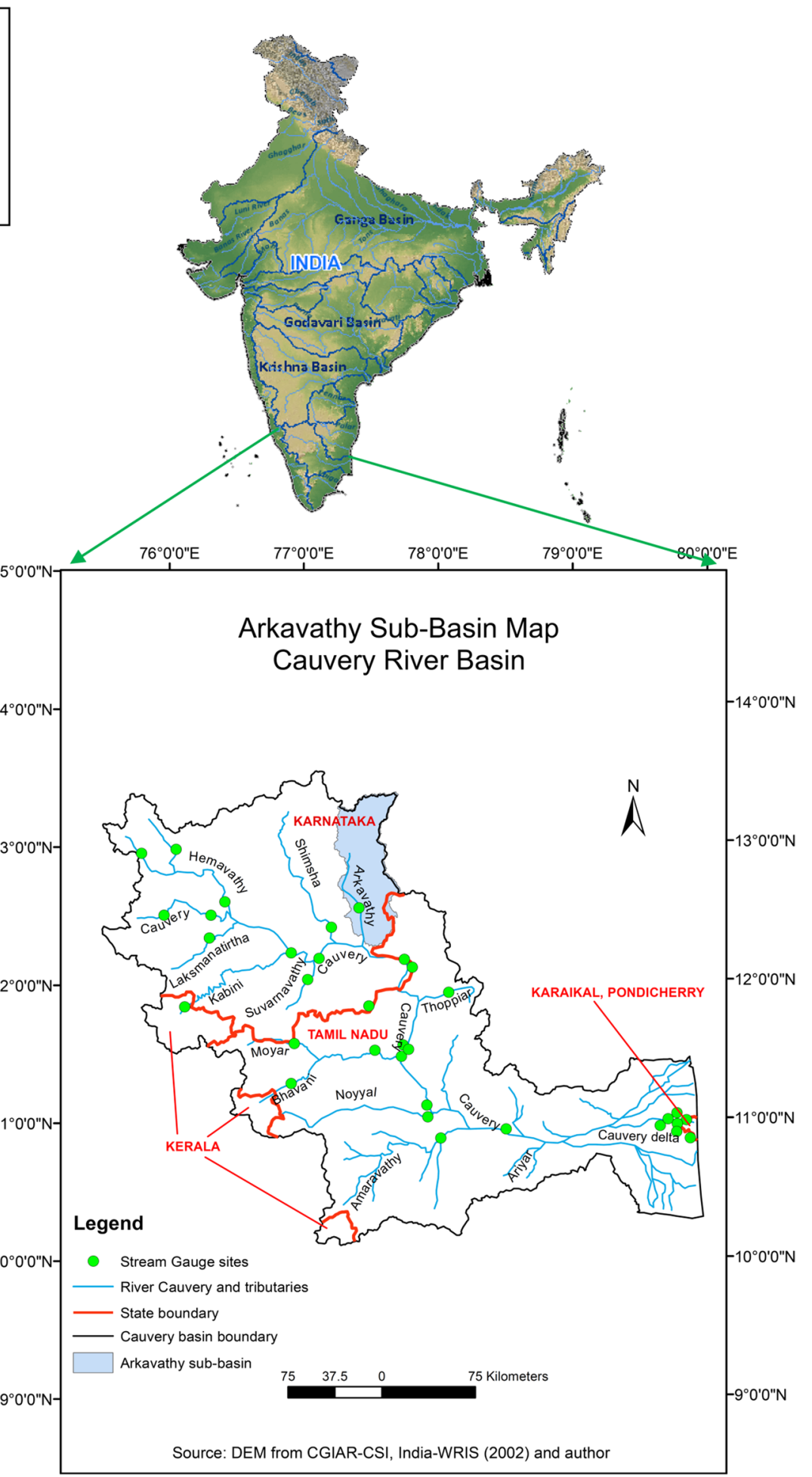

\section{Methodology}

Integrated use of remote sensing (RS) and geographic information system (GIS) techniques/tools has been adopted in the present study to delineate Arkavathy river basin, derive the stream network, derive and analyse morphologic parameters and hypsometric curve. NASA's Shuttle Radar Topography Mission (SRTM) mosaic digital elevation model (DEM) that covers $80 \%$ of globe at a resolution of $90 \mathrm{~m}$ at equator and $5^{\circ} \times 5^{\circ}$ tiles has been used to delineate the Arkavathy river basin (CSI-CGIAR 2018). The DEMs have been processed so that "no-data" voids are filled. 
Fig. 2 Stream network in Arkavathy river basin

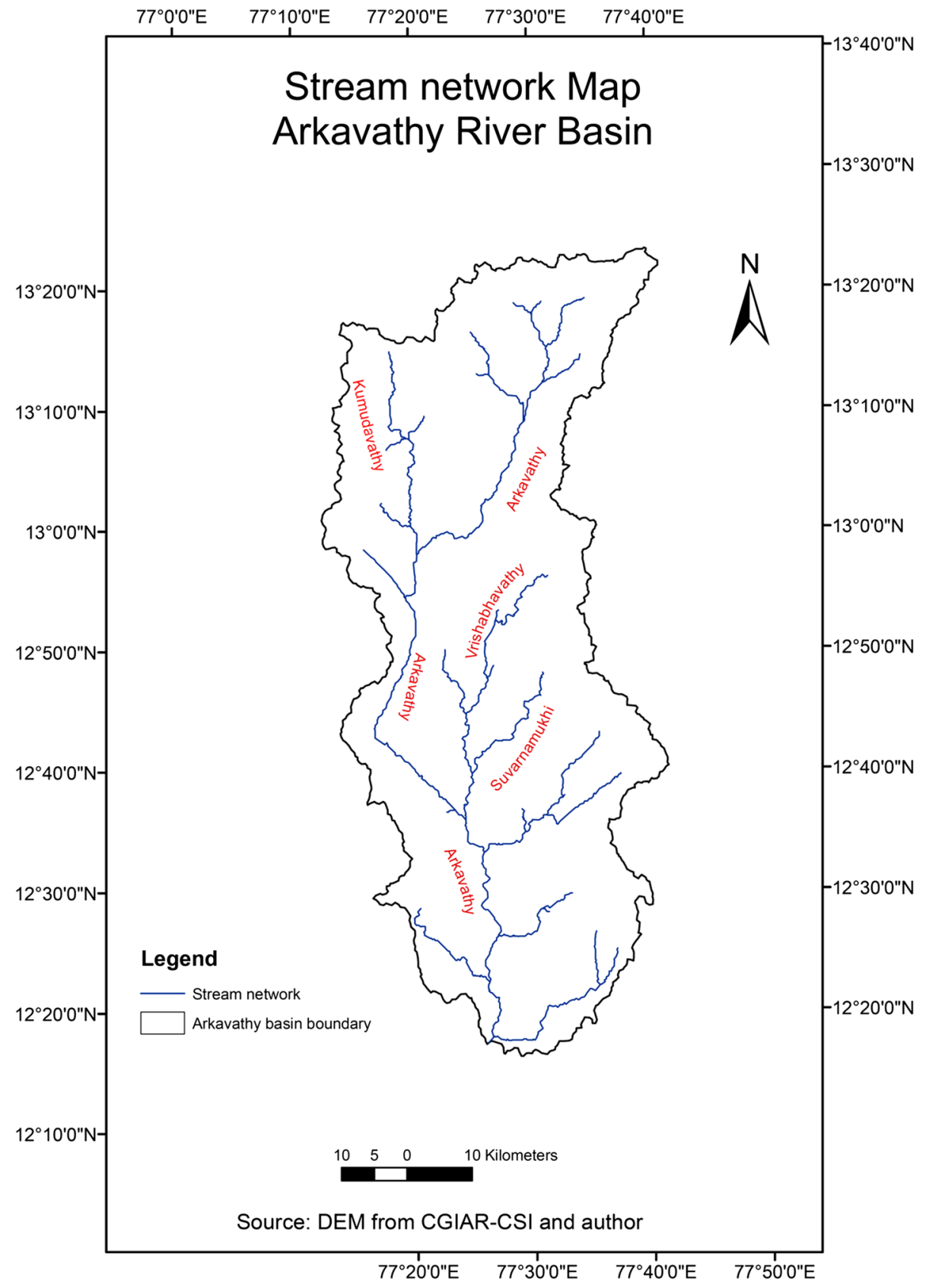

Survey of India (SoI) toposheets of 1:50,000 scale have also been used to verify the geo-referencing of the DEM. ArcHydro tools in ArcGIS 10.2 have been used to derive basin boundary, drainage pattern and watersheds within the basin to understand the morphological parameters. The steps followed are shown in Fig. 4. The longest drainage length was digitized and converted to vector data using ArcGIS 10.2. The derived basin boundary was then converted to vector data called "shapefile" from which the area and perimeter of Arkavathy river basin was calculated in attribute table of ArcGIS. Stream order in accordance with Strahler (1964) and stream length for each order in Arkavathy river basin were determined using ArcGIS 10.2. The formulae used to estimate morphometric parameters are shown in Table 2. The results are shown in Tables 3 and 4. Tables 3 and 4 show the morphometric parameters and characteristics of Arkavathy basin, respectively.

Hypsometric curve for Arkavathy river basin is derived using SRTM mosaic DEM and ArcGIS 10.2. In accordance with Vivoni et al. (2008), contour line representations were created in the original DEM of $90 \mathrm{~m}$ resolution in ArcGIS 10.2 at vertical resolution of $100 \mathrm{~m}$ for the basin relief of $1064 \mathrm{~m}$ (1435-371 m). However, close to highlands and lowlands the interval is restricted to $29 \mathrm{~m}$ and $35 \mathrm{~m}$, respectively. Using 
Fig. 3 Stream network across districts Ramanagar, Bengaluru Urban, Bengaluru Rural, Chikkaballapura in Karnataka and Krishnagiri District in Tamil Nadu

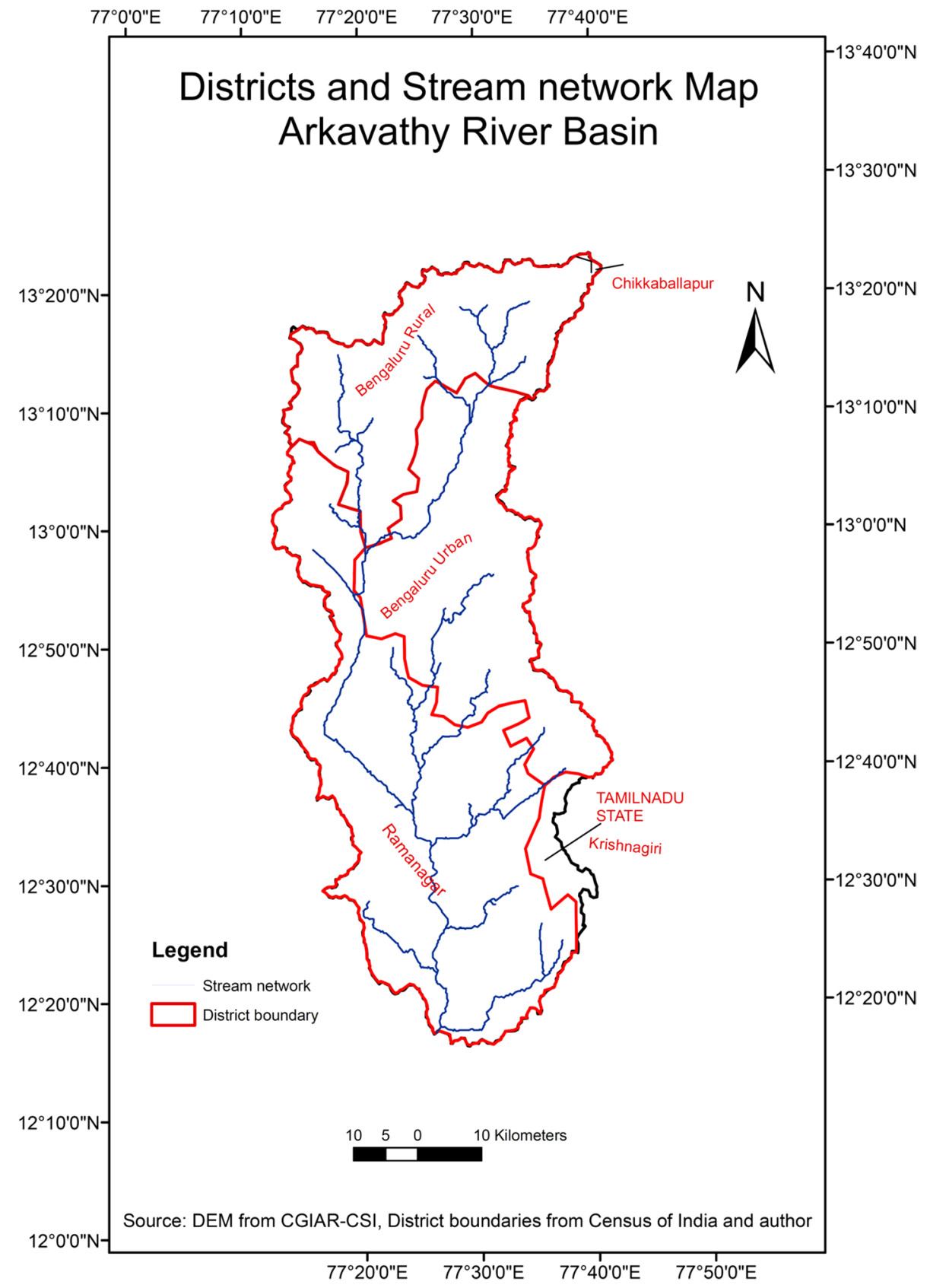

the DEM, the elevations between $1435 \mathrm{~m}$ (the highest elevation) and $371 \mathrm{~m}$ (the lowest elevation) in Arkavathy basin are classified into 12 classes considering the contour interval of $100 \mathrm{~m}$ as shown in Table 5. The contours are then derived in ArcGIS 10.2 (Fig. 5). The surface area between contours has been calculated in attribute table after conversion of reclassified raster showing contours to polygon feature in ArcGIS. The surface area within each contour class is merged using merge option in ArcGIS editor and raster calculator. The relative surface area above each contour (in accordance with Willgoose and Hancock 1998) is calculated by dividing the surface area between each contour class by the total area of the basin, i.e.
$4146.39 \mathrm{~km}^{2}$. The relative surface area is converted to percentage, and then, the cumulative relative surface area is derived in percentage. Similarly, the relative elevation or relative height (in percentage) of the basin is derived as $\frac{(e-371)}{E}$ where " $\mathrm{e}$ " is any contour height/elevation and " $E$ " is the relief of the basin, i.e. $1471 \mathrm{~m}-371 \mathrm{~m}=1064 \mathrm{~m}$. The difference of the selected contour elevation of the basin corresponding to the lowest elevation $(371 \mathrm{~m}$ ) divided by basin relief, i.e. $1064 \mathrm{~m}$, gives the relative height of the corresponding contour which is a dimensionless number. The relative surface area and relative height are expressed in percentage $(0-100 \%)$ for the purpose of better interpretation of hypsometric curve. By plotting the 
Fig. 4 Steps to delineate watershed, stream network and hypsometric curve in ArcGIS 10.2

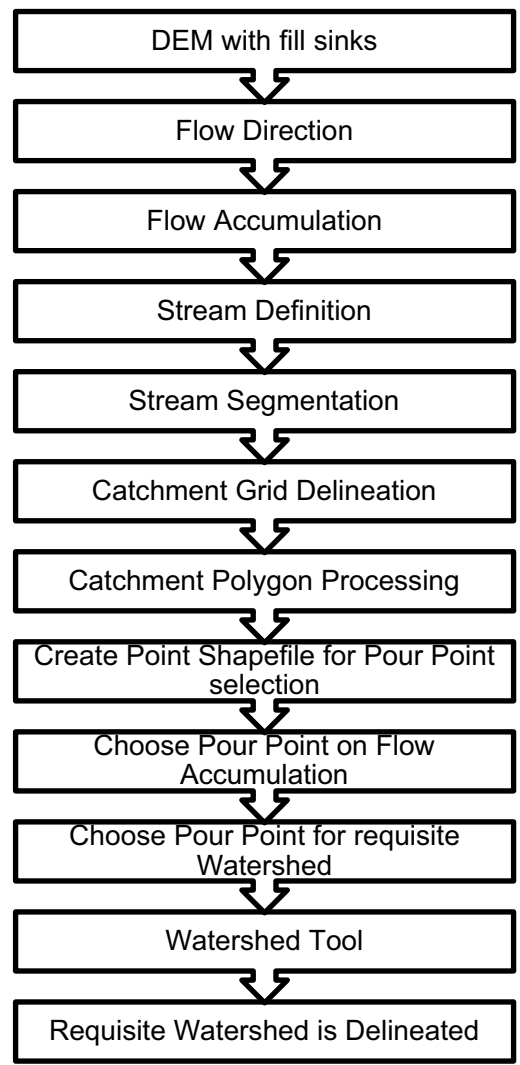

Steps followed for delineation of Arkavathy basin (HEC-GEOHMS, 2013)

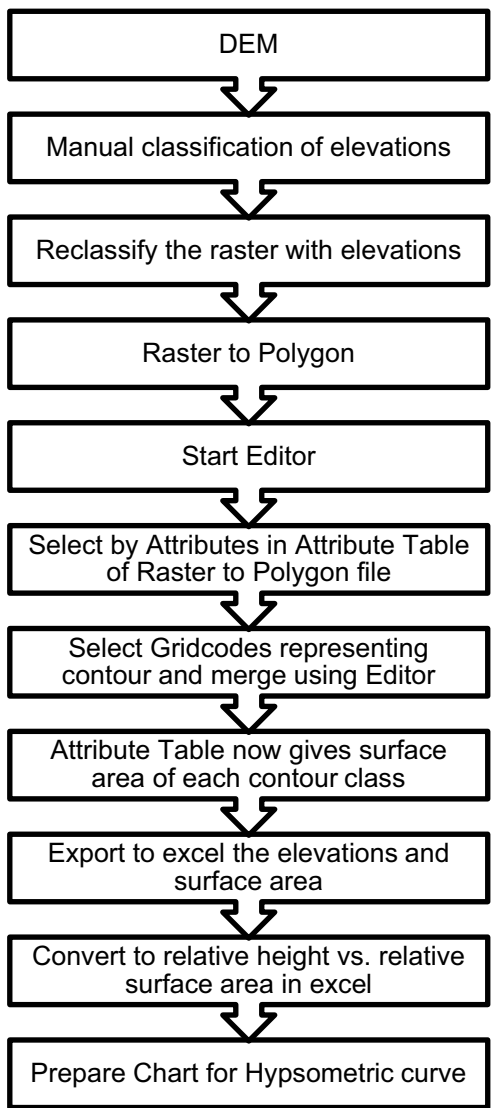

Steps followed for derivation of Hypsometric Curve percentage relative surface area against corresponding relative height of the basin, the hypsometric curve has been derived. The steps to derive the hypsometric curve are shown in Fig. 4. The values of relative surface area and relative height are shown in Table 5.

\section{Results and discussion}

The Arkavathy river basin morphological parameters such as linear, relief and areas aspects calculated are shown in Table 3, and the characteristics such as bifurcation ratio, stream length ratio and numbers of segments are shown in Table 4. The hypsometric curve for Arkavathy river basin is shown in Fig. 6a.

\section{Morphometric evaluation of Arkavathy river basin}

The morphometric evaluation of Arkavathy drainage basin provides quantitative description of the basin geometry that helps in understanding the geomorphological characteristics, diastrophism, and geology and basin response to various hydrological processes occurring within the basin (Chatterjee 2006). The evaluation and discussions are made classifying the morphometry of Arkavathy river basin into linear aspects, relief aspects and areal aspects.

\section{Linear aspects}

The drainage pattern in Arkavathy river basin is dendritic to sub-dendritic (Fig. 7). The dendritic pattern indicates the presence of uniform resistance of rock to the drainage in the basin. According to Petersen et al. (2017), dendritic patterns tend to develop in areas where the rocks have a roughly equal resistance to weathering and erosion and are not intensely jointed. Data from CGWB (2012) confirm that Arkavathy river basin is underlain with intrusive acidic rock and banded gneissic rock complex that is more or less uniform throughout the basin (Fig. 8). The change in mean stream length values from 1.92 to 44.5 indicates the change in elevation across the topography and the change in slope of the basin. That the basin is also undergoing erosion, despite the uniform resistance of rocks, is confirmed by the hypsometric curve which shows no sign of concavity in the surface area between uplands and lowlands (Fig. 6a). The morphometric 
Table 2 Formulae for estimation of morphometric parameters of Arkavathy basin

\begin{tabular}{|c|c|c|}
\hline Morphometric parameters & Formulae & References \\
\hline \multicolumn{3}{|l|}{ Linear aspects } \\
\hline Stream order $(\mathrm{U})$ & Hierarchical order & Strahler (1964) \\
\hline Stream length $\left(L_{\mathrm{u}}\right)$ & Length of the stream & Horton (1945) \\
\hline Mean stream length $\left(L_{\mathrm{sm}}\right)$ & $\begin{array}{l}L_{\mathrm{sm}}=L_{\mathrm{u}} / N_{\mathrm{u}} \text { where } L_{\mathrm{u}}=\text { stream length of order " } \mathrm{U} \text { " and } N_{\mathrm{u}}=\text { total number of stream seg- } \\
\text { ments of order "U" }\end{array}$ & Horton (1945) \\
\hline Stream length ratio $\left(R_{\mathrm{L}}\right)$ & $\begin{array}{l}R_{\mathrm{L}}=L_{\mathrm{u}} / L_{\mathrm{u}-1} \text { where } L_{\mathrm{u}}=\text { total stream length of order " } \mathrm{U} \text { " and } L_{\mathrm{u}-1}=\text { stream length of } \\
\text { next lower order }\end{array}$ & Horton (1945) \\
\hline Bifurcation ratio $\left(R_{\mathrm{b}}\right)$ & $\begin{array}{l}R_{\mathrm{b}}=N_{\mathrm{u}} / N_{\mathrm{u}+1} \text { where } \mathrm{N}_{\mathrm{u}}=\text { total number of stream segment of order " } \mathrm{u} \text { " and } N_{\mathrm{u}+1}=\text { num- } \\
\text { ber of segment of next higher order }\end{array}$ & Schumn (1956) \\
\hline \multicolumn{3}{|l|}{ Areal aspects } \\
\hline Drainage density $\left(D_{\mathrm{d}}\right)$ & $D_{\mathrm{d}}=L / A$ where $L=$ total length of streams and $A=$ area of watershed & Horton (1945) \\
\hline Stream frequency $\left(S_{\mathrm{f}}\right)$ & $S_{\mathrm{f}}=N_{\mathrm{s}} / A$ where $N_{\mathrm{s}}=$ total number of streams and $A=$ area of watershed $\left(\mathrm{km}^{2}\right)$ & Horton (1945) \\
\hline Texture ratio $(T)$ & $\begin{array}{l}T=N_{1} / P \text { where } N_{1}=\text { total number of first-order streams and } P=\text { perimeter of watershed } \\
\quad(\mathrm{km})\end{array}$ & Horton (1945) \\
\hline Form factor $\left(R_{\mathrm{f}}\right)$ & $R_{\mathrm{f}}=A /\left(L_{\mathrm{b}}\right)^{2}$ where $A=$ area of watershed $\left(\mathrm{km}^{2}\right)$ and $L_{\mathrm{b}}=$ basin length $(\mathrm{km})$ & Horton (1932) \\
\hline Circulatory ratio $\left(R_{\mathrm{c}}\right)$ & $\begin{array}{l}R_{\mathrm{c}}=4 \pi A / P_{2} \text { where } A=\text { area of watershed }\left(\mathrm{km}^{2}\right), \pi=3.14, \text { and } P=\text { perimeter of watershed } \\
\quad(\mathrm{km})\end{array}$ & Miller (1953) \\
\hline Elongation ratio $\left(R_{\mathrm{e}}\right)$ & $R_{\mathrm{e}}=2 \sqrt{ }(A / \pi) / L_{\mathrm{b}}$ where $A=$ area of watershed $\left(\mathrm{km}^{2}\right), \pi=3.14$, and $L_{\mathrm{b}}=$ basin length $(\mathrm{km})$ & Schumn (1956) \\
\hline Length of overland flow $\left(L_{\mathrm{of}}\right)$ & $L_{\mathrm{of}}=1 /\left(2 D_{\mathrm{d}}\right)$ where $D_{\mathrm{d}}$ is drainage density & Horton (1945) \\
\hline Constant of channel maintenance $(C)$ & $C=1 / D_{\mathrm{d}}$ where $D_{\mathrm{d}}=$ drainage density & Horton (1945) \\
\hline \multicolumn{3}{|l|}{ Relief aspects } \\
\hline Basin relief $\left(B_{\mathrm{h}}\right)$ & Vertical distance between the lowest and highest points of watershed & Schumn (1956) \\
\hline Relief ratio $\left(R_{\mathrm{h}}\right)$ & $R_{\mathrm{h}}=B_{\mathrm{h}} / L_{\mathrm{b}}$ where $B_{\mathrm{h}}=$ basin relief $(\mathrm{km})$ and $L_{\mathrm{b}}=$ basin length $(\mathrm{km})$ & Schumn (1956) \\
\hline Ruggedness number $\left(R_{\mathrm{n}}\right)$ & $R_{\mathrm{n}}=B_{\mathrm{h}} \times D_{\mathrm{d}}$ where $B_{\mathrm{h}}=$ basin relief and $D_{\mathrm{d}}=$ drainage density $\left(\mathrm{km} / \mathrm{km}^{2}\right)$ & Schumn (1956) \\
\hline
\end{tabular}

study and hypsometric curve reveals that due to progressive erosion, the existing water bodies in the basin are at risk of sedimentation with consequent loss of live storage leading to increased water stress in the basin. This explains partly the fact reported by Srinivasan et al. (2015), Arpita (2018) and Suresh (2001) that the water bodies and major reservoirs of the basin such as Thippagondanahalli and Hesaraghatta, that once supplied water and were lifeline to Bengaluru city, have been silted up.

The stream order in accordance with Strahler (1964) obtained for Arkavathy river basin is six, and therefore, the basin is designated as sixth-order basin. The stream order is derived from DEM and ArcGIS 10.2; however, further delineation of stream network is limited by its spatial resolution of $90 \mathrm{~m}$. The stream definition has been considered for an area as low as $2 \mathrm{~km}^{2}$ of Arkavathy basin in ArcGIS 10.2 that comprises 239 cells/pixels in ArcGIS for the derivation of sixth-order basin. For the current study, a stream order of six has been considered to minimize errors due to limitation in the resolution of DEM. Table 4 shows number of stream segments of all six-order stream segments in Arkavathy river basin. The geomorphic characteristics of Arkavathy river basin confirm to Horton (1932) that the number of stream segments of different orders decreases with increase in stream order. From the different-order stream segments in Arkavathy river basin, it is observed that the number of stream segments in stream orders 1 and 2 possesses large number of stream segments. Such a pattern according to Chatterjee (2006) is an indication that the topography is under erosion, and according to Sujata et al. (2013), the pattern is attributed to anomalous basin development, local variation in topography and effect of localized geological disturbance.

Bifurcation ratio is the foremost parameter linking the hydrological regime in a basin (Raj et al. 1999). It is an important indicator of relief and dissection of the basin. In Arkavathy basin, bifurcation ratio shows variation from 2 to 5.50 (with a mean of 3.78) across different stream orders (Table 4). According to Yangchan (2015), any basin with bifurcation ratio within range of 3.0 to 5.0 indicates that the geologic structures do not distort the drainage pattern within that basin, whereas Rao (2016) states that any bifurcation ratio less than 3.0 indicates lack of structural control and that more than 5.0 shows structural control over formation of drainage pattern. In Arkavathy river basin, as the bifurcation ratio for stream order 3 and stream order 5 is less than 3.0 ( 2.75 and 2 , respectively), it can be inferred that there is less structural control for streams of orders 3 and 5. This indicates flat terrain specifically across regions where streams of orders 3 and 5 are located, whereas an increase in bifurcation 
Table 3 Morphometric parameters of Arkavathy river basin

\begin{tabular}{|c|c|c|c|c|}
\hline Sl. no. & Morphometric parameters & $\begin{array}{l}\text { Values for Arka- } \\
\text { vathy river basin }\end{array}$ & Unit & $\begin{array}{l}\text { Morphomet- } \\
\text { ric evalua- } \\
\text { tion }\end{array}$ \\
\hline 1 & Basin area $(A)$ & 4146.39 & $\mathrm{~km}^{2}$ & - \\
\hline 2 & Basin perimeter $(P)$ & 425.11 & $\mathrm{~km}$ & - \\
\hline 3 & Basin length $(L)$ & 165.87 & $\mathrm{~km}$ & - \\
\hline 4 & Basin width $(W)$ & 25 & $\mathrm{~km}$ & - \\
\hline 5 & Highest stream order (U) & 6 & No & - \\
\hline 6 & No. of stream segments & 716 & No & - \\
\hline 7 & Stream length $(L)$ & 2160.7 & $\mathrm{~km}$ & - \\
\hline 8 & Mean stream length & 360.11 & $\mathrm{~km}$ & - \\
\hline 9 & Mean stream length ratio $\left(R_{\mathrm{L}}\right)$ & 2.01 & No & - \\
\hline 10 & Bifurcation ratio $\left(\mathrm{R}_{\mathrm{b}}\right)$ & Mean 3.78 & No & - \\
\hline 11 & Length of overland flow $\left(L_{\mathrm{of}}\right)$ & 0.96 & $\mathrm{~km}$ & High \\
\hline 12 & Form factor $\left(R_{\mathrm{f}}\right)$ & 0.15 & No & Low \\
\hline 13 & Texture ratio $(T)$ & 1.32 & $\mathrm{~km}^{-1}$ & Low \\
\hline 14 & Circulatory ratio $\left(R_{\mathrm{c}}\right)$ & 0.288 & No & Low \\
\hline 15 & Elongation ratio $\left(R_{\mathrm{e}}\right)$ & 0.25 & No & Low \\
\hline 16 & Compaction coefficient & 1.863 & No & High \\
\hline 17 & Drainage density $\left(D_{\mathrm{d}}\right)$ & 0.52 & $\mathrm{~km} / \mathrm{km}^{2}$ & Low \\
\hline 18 & Constant of channel maintenance (C) & 1.92 & $\mathrm{~km}$ & - \\
\hline 19 & Stream frequency $\left(F_{\mathrm{s}}\right)$ & 0.172 & per sq km & Low \\
\hline 20 & Basin relief $\left(B_{\mathrm{h}}\right)$ & 1064 & $\mathrm{~m}$ & High \\
\hline 21 & Relief ratio $\left(R_{\mathrm{h}}\right)$ & 0.007 & No & High \\
\hline 22 & Ruggedness number $\left(R_{\mathrm{n}}\right)$ & 546 & No & High \\
\hline
\end{tabular}

Table 4 Morphometric characteristics of Arkavathy river basin

\begin{tabular}{|c|c|c|c|c|c|c|c|}
\hline Stream order & $\begin{array}{l}\text { No of seg- } \\
\text { ments }\left(N_{\mathrm{u}}\right)\end{array}$ & $\begin{array}{l}\text { Stream length } \\
(L)(\mathrm{km})\end{array}$ & $\begin{array}{l}\text { Bifurcation ratio } \\
\left(R_{\mathrm{b}}\right), N_{\mathrm{u}} /\left(N_{\mathrm{u}+1}\right)\end{array}$ & $\begin{array}{l}\text { Mean stream length, } \\
(\mathrm{km}), L_{\mathrm{u}}=L / N_{\mathrm{u}}\end{array}$ & $\begin{array}{l}\text { Cumulative } \\
\text { length, (km) }\end{array}$ & $\begin{array}{l}\text { Cumulative num- } \\
\text { ber of segments }\end{array}$ & $\begin{array}{l}\text { Stream length } \\
\text { ratio, } L_{\mathrm{u}} / L_{\mathrm{u}-1}\end{array}$ \\
\hline 1 & 562 & 1081.4 & 4.64 & 1.92 & 1081.4 & 562 & \\
\hline 2 & 121 & 584.8 & 5.50 & 4.83 & 1666.2 & 683 & 2.51 \\
\hline 3 & 22 & 215 & 2.75 & 9.77 & 1881.2 & 705 & 2.02 \\
\hline 4 & 8 & 137 & 4 & 17.13 & 2018.2 & 713 & 1.75 \\
\hline 5 & 2 & 98 & 2 & 49 & 2116.2 & 715 & 2.86 \\
\hline 6 & 1 & 44.5 & & 44.50 & 2160.7 & 716 & 0.91 \\
\hline Total & 716 & 2160.7 & Mean 3.78 & Mean 21.19 & & & Mean 2.01 \\
\hline
\end{tabular}

ratio above 3.0 for stream orders 1 and 4 indicates local rugged topography at uplands and lowlands, but specifically at locations where streams of orders 1 and 4 are prevalent. The bifurcation ratio for stream order 2 is 5.5 , which is above 5.0, indicating the presence of structural control and geological disturbances in streams of order 2 (Sujata et al. 2013).

The consequence of low bifurcation ratio according to Kulkarni (2015) is that there will be higher possibilities of flooding. Therefore, it can be deduced that, for stream orders 3 and 5 having low bifurcation ratios of 2.75 and 2.0 , respectively, water tends to accumulate rather than spreading out. In contrast, possibility of flooding is low for the stream orders 1,2 , and 4 which have higher bifurcation ratios of 4.64, 5.5 and 4, respectively, because the energy of flow is low, thereby increasing the scope for infiltration in these stream orders (Al Saud 2009). Therefore, coupled with human interventions observed extensively across the basin there is increased flood risk in Arkavathy river basin for streams of orders 3 and 5 that also depends on combination of factors such as the intensity of precipitation, vegetation cover and nature of such human intervention. However, according to Paul and Bayode (2012), the time of peak, time of concentration and the peak discharge are dependent on the shape of the basin. Another important 
Table 5 Derivation of hypsometric curve

\begin{tabular}{|c|c|c|c|c|c|c|}
\hline Sl. no. & $\begin{array}{l}\text { Elevation reclassified in ArcGIS } \\
\text { (contour interval } 100 \mathrm{~m} \mathrm{~b} / \mathrm{n} \mathrm{Sl} \text {. } \\
\text { No. } 2 \text { to No.11) }\end{array}$ & $\begin{array}{l}\text { Surface area } \\
\text { between contours, } \\
a\left(\mathrm{~km}^{2}\right)\end{array}$ & $\begin{array}{l}\text { Surface } \\
\text { area, } \frac{a}{A} \\
(\%)\end{array}$ & $\begin{array}{l}\text { Accumulated relative surface } \\
\text { area above contour elevation } \\
\frac{a}{A}(\%)\end{array}$ & $\begin{array}{l}\text { Contour } \\
\text { elevation/ } \\
\text { height, } e(\mathrm{~m})\end{array}$ & $\begin{array}{l}\text { Relative height/ } \\
\text { elevation } \frac{(e-371)}{E} \\
(\%)\end{array}$ \\
\hline & & & & 0 & 1435 & 100.00 \\
\hline 1 & $1400-1435$ & 4.50 & 0.11 & 0.11 & 1400 & 96.71 \\
\hline 2 & $1300-1400$ & 19.36 & 0.47 & 0.58 & 1300 & 87.31 \\
\hline 3 & $1200-1300$ & 100.31 & 2.42 & 2.99 & 1200 & 77.91 \\
\hline 4 & $1100-1200$ & 696.24 & 16.79 & 19.78 & 1100 & 68.52 \\
\hline 5 & $1000-1100$ & 1015.68 & 24.49 & 44.28 & 1000 & 59.12 \\
\hline 6 & $900-1000$ & 1429.37 & 34.47 & 78.74 & 900 & 49.72 \\
\hline 7 & $800-900$ & 865.29 & 20.87 & 99.61 & 800 & 40.32 \\
\hline 8 & $700-800$ & 10.84 & 0.26 & 99.87 & 700 & 30.92 \\
\hline 9 & $600-700$ & 3.72 & 0.09 & 99.96 & 600 & 21.52 \\
\hline 10 & $500-600$ & 1.01 & 0.02 & 99.99 & 500 & 12.12 \\
\hline 11 & $400-500$ & 0.53 & 0.01 & 100 & 400 & 2.73 \\
\hline \multirow[t]{2}{*}{12} & $371-400$ & 0.06 & 0.00 & 100 & 371 & 0 \\
\hline & Total area $(A)$ & 4146.39 & & & $\begin{array}{l}E=1064 \\
\quad(1435-371)\end{array}$ & \\
\hline
\end{tabular}

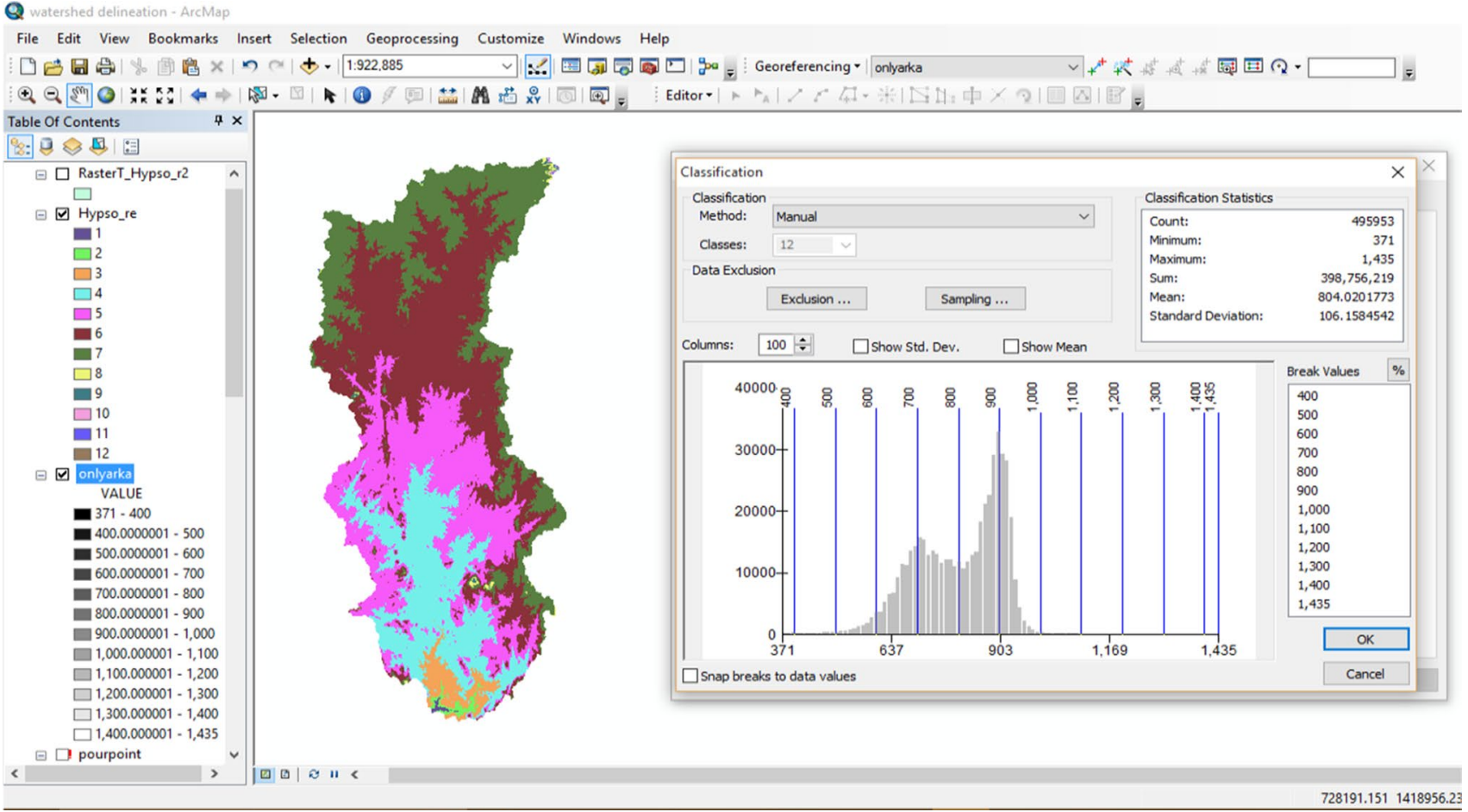

Fig. 5 Comparison of hypsometric curve of Arkavathy river basin

observation from the results in Table 4 is that the stream lengths of orders 1,2 and 4 constitute $83.5 \%$ of the total length of the stream network that indicate higher scope for infiltration, which can be utilized through construction of ground water recharge structures across these stream orders.

\section{Relief aspects}

The relief measure of a basin indicates the potential energy of a drainage basin because a region having a high relief can transfer high energy into the drainage system (Yangchan et al. 2015). The relief in Arkavathy river basin is found to 


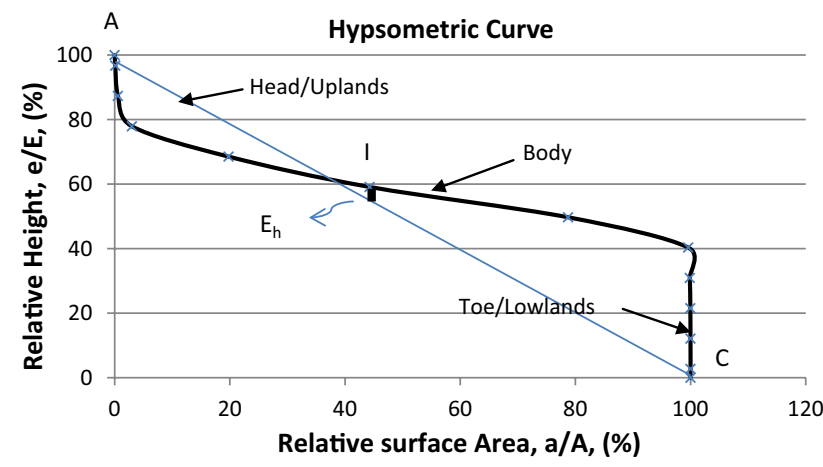

(a) Hypsometric curve of Arkavathy river basin

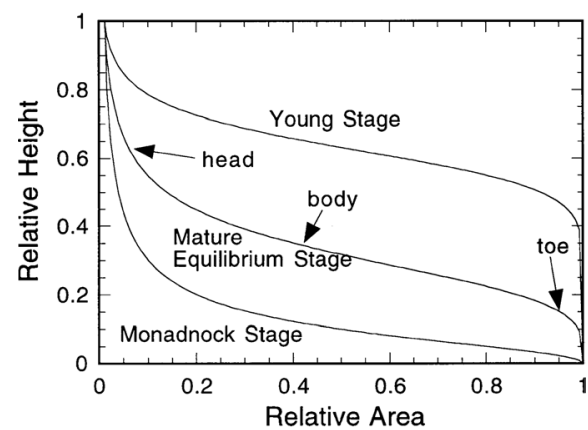

(b) Hypsometric curve classification (Source: Willgoose and Hancock, 1998)

Fig. 6 Classification of Arkavathy river basin as contour line classes at 100-m interval in ArcGIS 10.2 for derivation of hypsometric curve in Arkavathy river basin

be high at $1064 \mathrm{~m}$ with the highest elevation $1435 \mathrm{~m}$ above the mean sea level found in the north-eastern tip of the basin located in Chikkaballapur District and the lowest elevation of $371 \mathrm{~m}$ above mean sea level in the southern tip at the confluence of Arkavathy river with Cauvery river at Mekedatu, Kanakapura taluk, Ramanagara District.

The higher relief found in Arkavathy river basin indicates greater energy available in the drainage system of the basin. Despite higher relief, the infiltration characteristics in the basin depend on numerous variables such as slope of the terrain (such as steep slope of uplands and lowlands in the basin and flat terrain in between), rainfall, vegetation, subsurface material and the nature of human interference in the basin across various stream orders which is also reflected by the drainage density (Oyatayo et al. 2017; Sukristiyanti et al. 2018). So, the infiltration characteristics vary within the basin. The greater energy at steep uplands and lowlands causes quicker drainage with less scope for infiltration into the ground at these locations, whereas the flat terrain shown by hypsometric curve in between showing moderate to less slope possesses different infiltration characteristics in accordance with (Oyatayo et al. 2017). Another consequence of the higher energy is the scope for erosion in the basin, particularly at locations closer to steeper relief. Referring to the hypsometric curve of the basin (Fig. 6a), it is clear that the elevation at lowlands (toe region) is steep, as less surface area $(<5 \%)$ is covered in the lowlands for elevations of up to $40 \%$, and similarly, about $20 \%$ (80 to $100 \%$ ) elevation at uplands (head region) is covered by the surface area of about $0-5 \%$. The hypsometric curve shows the steepness of topography within 5\% of the surface area in both the uplands and lowlands, whereas there is relatively flat surface area in between. So, any runoff generated at uplands and lowlands possesses the tendency to drain out quickly due to the steepness of topography. Due to its steepness, the dissected uplands and lowlands are conducive for construction of surface storage structures, whereas ground water recharge structures and smaller water harvesting structures can be built in the flatter terrain also classified in geomorphological term as pediment-piedmont region.

\section{Areal aspects}

Areal aspects of morphometry are crucial in assessment of runoff particularly the contribution of overland flow to the stream network that depends on the shape and slope of the terrain besides relief and linear aspects. Some of the indices that have quantitatively assessed in areal aspects are form factor, elongation ratio, circulatory ratio, compaction coefficient, drainage density, stream frequency and length of overland flow.

The visual examination of shape of the Arkavathy river basin in (Fig. 2) shows that it is an elongated. But, the areal indices estimated for the basin confirm this assessment. On examination of the indices/parameters shown in Table 3, it is observed that the form factor for Arkavathy river basin is 0.15 which is low. According to Rai et al. (2014), form factor would always be greater than 0.78 for perfectly circular basin and the smaller the value of form factor, the more elongated will be the basin. The circularity ratio and elongation ratio of Arkavathy river basin are 0.288 and 0.25 , respectively, which are low. The compaction coefficient of the basin is 1.823 which is high in comparison with the value stated by Paul and Bayode (2012). According to Waikar and Nilawar (2014), basins with elongation ratio higher than 0.9 are circular in shape, and basins with elongation ratio less than 0.7 are elongated. The value of 0.288 circularity ratio and elongation ratio of 0.25 for Arkavathy river basin shows that the basin is highly elongated and possesses steep slope at uplands and lowlands, which is also confirmed by the relief and hypsometric curve of the basin. The consequence of the confirmation of elongated nature of Arkavathy river basin is the reduced peak discharge of runoff in the basin.

Drainage density of a basin evaluates the erosion status of a basin (Bates 1981). Regions with high drainage 
Fig. 7 Drainage pattern of Arkavathy river basin

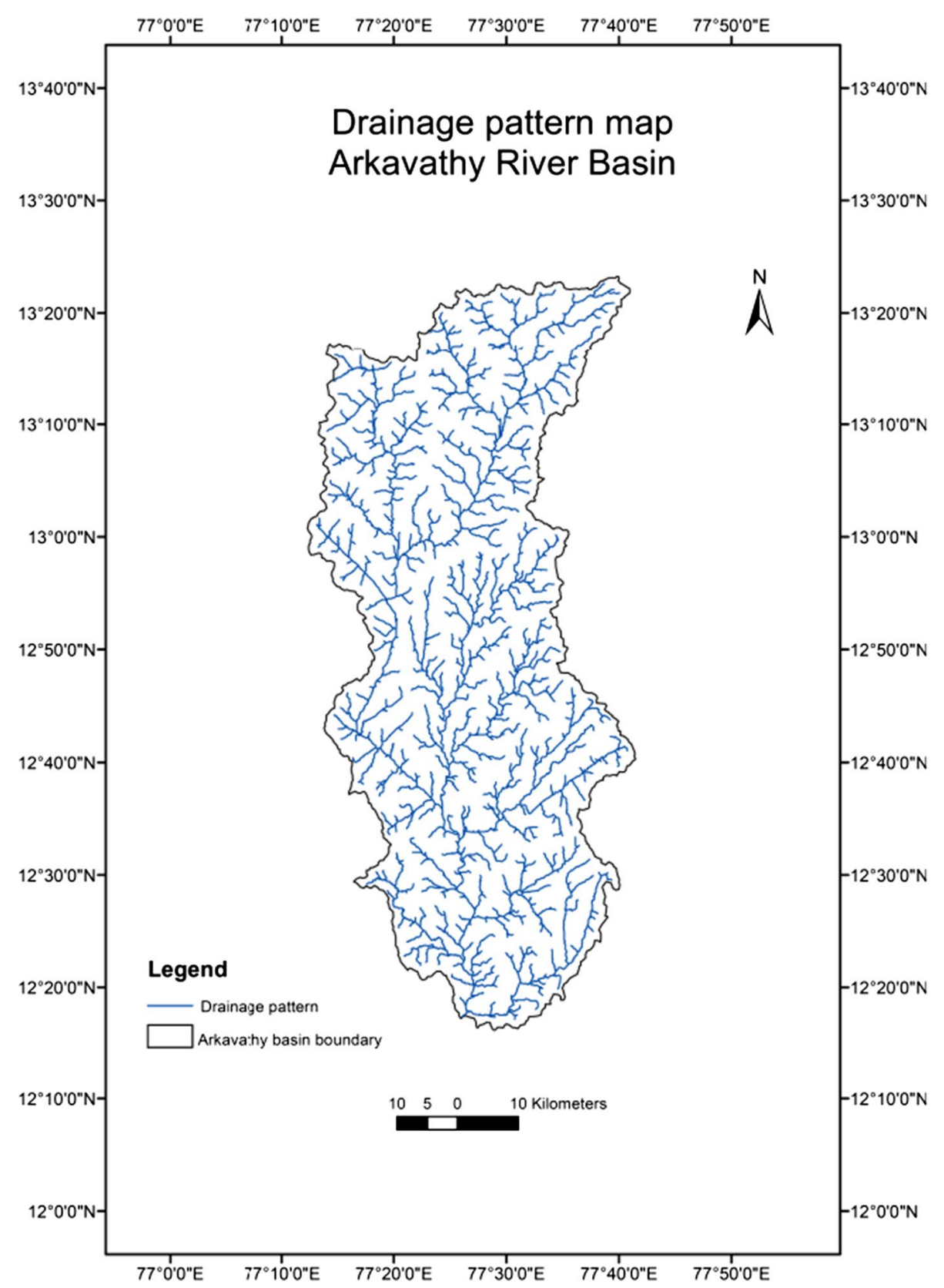

densities possess less infiltration, increase runoff and possess at least moderately erodible surface materials (Petersen et al. 2017). Higher the drainage density, the greater the amount of runoff and the significant the degree of channel abrasion for a given rainfall (Eze and Efiong 2010). From the results for Arkavathy river basin, it is observed that the drainage density for the basin is low, i.e. 0.52 . Similarly, the stream frequency is 0.172 which is also low. According to Pallard et al. (2009), one direct effect of decrease in drainage density is decreasing flood volumes that is attributed to long concentration times implying more opportunities for water to infiltrate. The length of overland flow for Arkavathy basin is 0.96 that confirms longer concentration time and non-existence of young topography Nongkynrih and Husain (2011). However, the drainage density of the basin and the long concentration time are dependent not only on the relief but also dependent on the resistance of rocks across different stream orders, vegetation, rainfall and sub-surface material. The large portion of the basin ( $80 \%$ of the basin) is flatter terrain as depicted by hypsometric curve of the basin. And the average annual rainfall in the basin is lowly $874.87 \mathrm{~mm}$. And the drainage density of the basin shows a low value of 0.52 and long overland flow value of 0.96 . Therefore, there is scope for higher infiltration reflected by low drainage density in regions of the flatter terrain.

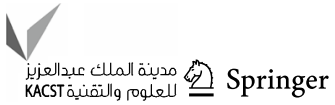


Fig. 8 Lithology in Arkavathy river basin

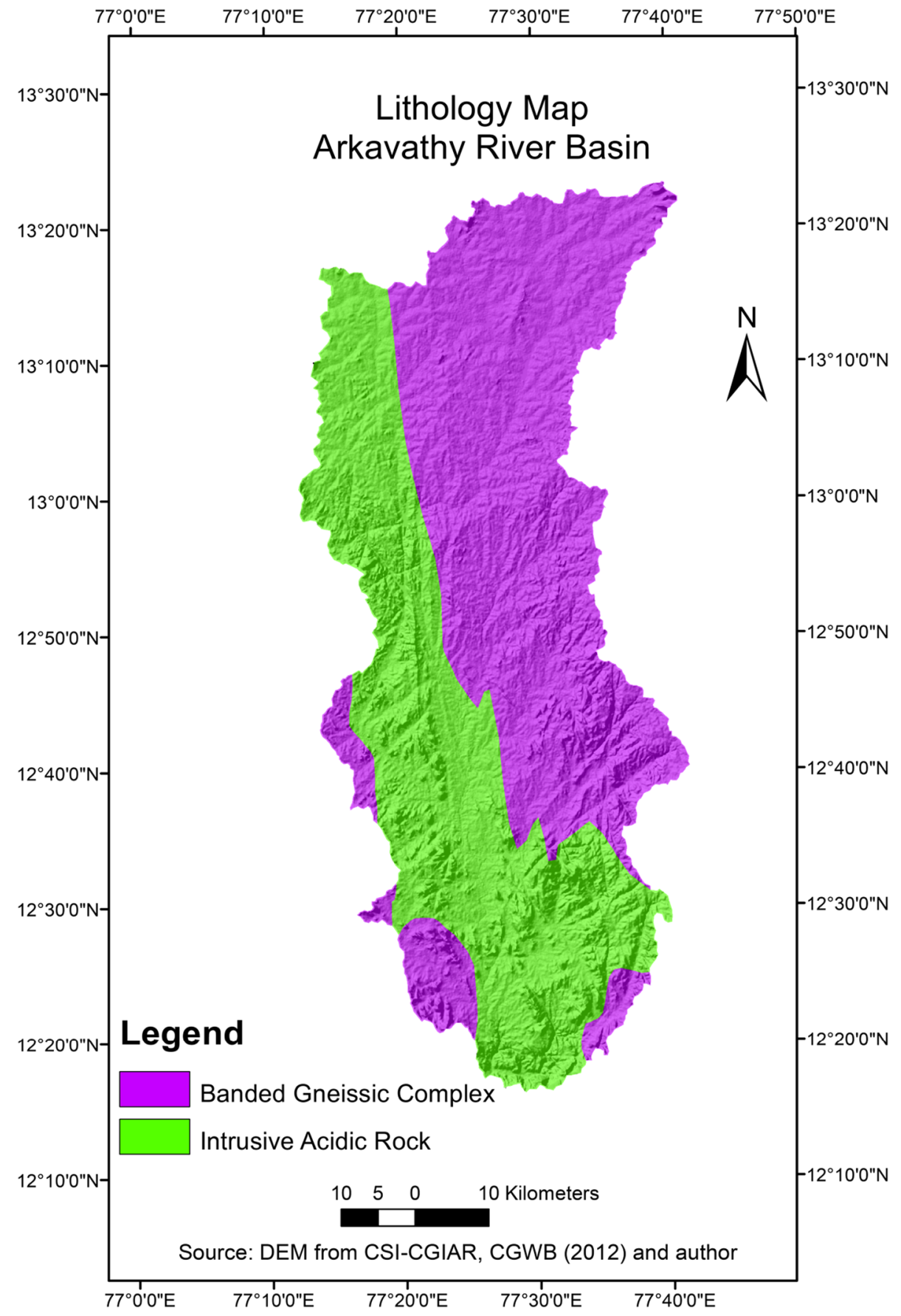

\section{Description of head and toe of hypsometric curve}

Figure 6a shows the hypsometric curve derived for Arkavathy river basin. Referring to the curve, the downward vertical part is termed as "toe" of the hypsometric curve and the concave upward part at the left hand side of the curve is termed "head" and the part of the curve in between "head" and "toe" is called "body" of the hypsometric curve. The region showing concavity, i.e. "head" and close to "head", is an indication that the region is predominated by erosion and the eroded materials are accumulating in the downstream (Chattopadhyay et al. 1996).

\section{Relation between morphological parameters and hypsometric curve}

Hypsometry is strongly dependent on drainage network and basin geometry. For example, the width-to-length ratio of the basin also known as "aspect ratio" influences the shape of 
the hypsometric curve significantly (Willgoose and Hancock 1998). According to Keller and Pinter (1996), hypsometric curves show the stage of development of drainage network. These curves provide information not only on the erosion status of the basin but also the tectonic, climate and lithological factors controlling it (Sarp et al. 2011). The relief ratio and catchment volume captured through hypsometric curve are useful in determining runoff and other hydrological processes (Vivoni et al. 2008). According to Sinha Roy (2002), as the aspect ratio declines, the drainage network becomes highly branched leading to higher bifurcation ratio. Then, for low aspect ratio, the toe height will be of increasing elevation at the downstream part of the basin.

For Arkavathy river basin, the morphological parameters such as form factor, circularity ratio and elongation ratio show that the basin is elongated. In other words, the basin exhibits low aspect ratio. Therefore, in accordance with Sinha Roy (2002), amongst different stream orders of Arkavathy river basin, it is observed that streams of order no 1 , 2 and 4 are in possession of higher bifurcation ratio of more than 3.0. Analysing the number of stream segments $\left(\mathrm{N}_{\mathrm{u}}\right)$ shown in Table 4, out of the total number of stream segments of 716 identified in the basin, the sum of the number of stream segments for stream order no. 1, 2 and 4 is 691 $(=561+121+8)$ or about $96.50 \%$ of stream segments in Arkavathy river basin possess higher bifurcation ratio. The outcome of the impact of morphological parameters on hypsometric curve can be observed in Fig. 6a that clearly depicts toe in the downstream part of the curve with increased elevation followed by slight concavity.

\section{Comparison of hypsometric curve of Arkavathy river basin}

Figure 6a shows the hypsometric curve of Arkavathy river basin, and Fig. $6 \mathrm{~b}$ shows three different types of hypsometric curve classified as (1) young stage, (2) mature equilibrium stage and (3) monadnock stage (Monadnock stage means subdued terrain with isolated elevated regions of resistant rock as per Willgoose and Hancock 1998). According to Sarp et al. (2011), convex hypsometric curves depict young and slightly eroded regions (the top most hypsometric curve in Fig. 6b), S-shaped curves (like the middle or second curve in Fig. 6b depict moderately eroded regions, and then the concave curves, i.e. the bottom most curve in Fig. 6b, point to old and highly eroded regions.

From the comparison of the hypsometric curve derived for Arkavathy river basin with the classification shown in Fig. 6b, it is clear that the hypsometric curve derived for Arkavathy river basin resembles closer to the convex hypsometric curve shown as top most curve in Fig. 6b with less head in upstream and greater toe height in downstream than the S-shaped curve in the middle or concave curve in the bottom of Fig. 6b. Therefore, from the comparison it can be inferred that the basin under study certainly has not attained mature equilibrium stage. Rather, the erosion status in the basin has moved beyond young stage but possesses considerable scope for erosion in the future before it attains mature equilibrium stage.

Further, a line A-C has been drawn for the hypsometric curve derived for Arkavathy river basin to verify the departure of the actual landform surface from the line A-C. If "I" is the inflection point of the curve, i.e. the point changing from concave downwards to concave upwards (or convex), and the $\mathrm{E}_{\mathrm{h}}$ is the vertical height between "I" and the hypsometric curve, it is clear that $\mathrm{E}_{\mathrm{h}}$ is minimal but above the line A-C which is considered as negative by Sinha Roy (2002). According to Sinha Roy (2002), $\mathrm{E}_{\mathrm{h}}$ is negative in immature and young landforms when the hypsometric curve lies above $\mathrm{A}-\mathrm{C}$, whereas in mature and old landforms, $\mathrm{E}_{\mathrm{h}}$ is positive. Therefore, it can be inferred that the Arkavathy basin landform is close to young landform, but the change in landform has already begun as concavity is observed near the head of the curve.

\section{Conclusions}

The study of hypsometric curve reveals that Arkavathy river basin is close to young but not old type of basin. Hence, the basin possesses considerable scope for erosion in future. The presence of flatter terrain in midlands in between uplands and lowlands is confirmed by hypsometric curve. And that puts existing reservoirs and water bodies across midlands at risk of sedimentation and loss of crucial live storage which will lead to accentuation of water stress in the basin.

Morphological characteristics of the basin indicate variation in different stream orders that confirms the anomalous basin development and local variation in topography in the basin. The dendritic to sub-dendritic pattern indicates uniform resistance to drainage pattern by major rock types in the basin such as intrusive acidic rock and banded gneissic rock. Along with the combination of factors such as human intervention and intensity of precipitation, flooding is expected across stream orders 3 and 5 due to lower bifurcation ratios, whereas stream orders 1,2 , and 4 possess increased scope for infiltration that facilitate building water harvesting and recharge structures. The steeper slopes at highlands and lowlands depicted by hypsometric curve, particularly at the regions across stream orders 3 and 5, have the potential to conserve water through large surface water harvesting structures.

The areal aspects of the Arkavathy river basin confirm that the basin is elongated and as a consequence Arkavathy river basin experiences low peak flows of runoff for longer

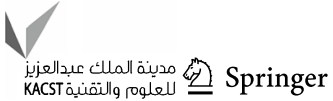


duration despite flood risk. Lower drainage density and length of overland flow in the basin confirm longer concentration times for runoff particularly in the regions of lower relief. Therefore, the runoff in Arkavathy river basin has large scope for infiltration into the ground water particularly at flatter regions depicted by hypsometric curve. However, as Arkavathy river basin possesses moderate- to low-waterbearing aquifer systems such as granite and gneiss rock types, the water infiltrated can only be stored across fluvial deposits across the valley floors and stream channels of the drainage network or in rock fractures. As the aquifer systems in Arkavathy basin are not high-water-bearing systems, considering the water budget of the basin, the cause of loss of water in a basin can be deduced as evapotranspiration. It can be concluded that due to high time of concentration of runoff in the basin, as a consequence of its morphometry, the loss of water due to evapotranspiration rates leads to the persistent water scarcity in the basin.

\section{Compliance with ethical standards}

Conflict of interest The authors declare that they have no conflict of interest.

Open Access This article is licensed under a Creative Commons Attribution 4.0 International License, which permits use, sharing, adaptation, distribution and reproduction in any medium or format, as long as you give appropriate credit to the original author(s) and the source, provide a link to the Creative Commons licence, and indicate if changes were made. The images or other third party material in this article are included in the article's Creative Commons licence, unless indicated otherwise in a credit line to the material. If material is not included in the article's Creative Commons licence and your intended use is not permitted by statutory regulation or exceeds the permitted use, you will need to obtain permission directly from the copyright holder. To view a copy of this licence, visit http://creativecommons.org/licenses/by/4.0/.

\section{References}

Al Saud M (2009) Morphometric analysis of Wadi Aurnah drainage system, Western Arabian Peninsula. Open Hydrol J 3:1-10

Arpita P (2018) 16,000 truckloads of silt to be removed from Hesaraghatta dam. The Times of India. 19th June 2018

Bates N (1981) Valley shapes. In: Knap B (ed) Practical foundations of physical geography. George Allen \& Unwin, London, pp 25-29

CGWB (2012) Aquifer systems of Karnataka. Ministry of Water Resources. Government of India: Bangalore.

CSI-CGIAR (2018) Retrieved at https://cgiarcsi.community/data/ srtm-90m-digital-elevation-database-v4-1/

Chatterjee A, Tantuley A (2006) Morphometric analysis for evaluating groundwater potential zones. In Kusangai Jor Watershed Area, Dist. Bolangir, Orissa. ISPRS. Conference proceedings, XXXVI (4). Retrieved at https://www.isprs.org/proceedings/ $\mathrm{XXXVI/part4/}$
Chattopadhyay S, Sajikumar S, Saritha D (1996) Integrated resource evaluation of the Vamanapuram river basin, South Kerala, Centre for Earth Science Studies, Technical Report, 65

Department of Agriculture (2018) Government of Karnataka, India. Bengaluru. Retrieved at https://raitamitra.kar.nic.in/stat/kacz. htm

Eze BE, Efiong J (2010) Morphometric parameters of the Calabar River Basin: implication for hydrologic processes. J Geogr Geol 2(1):18-26

Guth PL (2011) Drainage basin morphometry: a global snapshot from the shuttle radar topography mission. Hydrology and Earth System Sciences. Copernicus Publications. European Geosciences Union. https://doi.org/10.5194/hess-15-2091-2011

HEC-GEOHMS (2013) Geospatial hydrological modelling extension. User's manual. Version 10.1. CPD-77. US Army Corps of Engineers, Davis

Horton RE (1932) Drainage basin characteristic. Trans Am Geophys Union 14:350-361

Horton RE (1945) Erosional development of stream and their drainage basin: hydrological approach to quantitative morphology. Bull Geol Soc Am 56:275-370

Keller EA, Pinter N (1996) Active tectonics: earthquakes, uplift and landscape. Prentice Hall, New Jersey

Kulkarni MD (2015) The basic concept to study morphometric analysis of river drainage basin: a review. Int J Sci Res 4(7):2277-2280

Miller VC (1953) A quantitative geomorphic study of drainage basin characteristics in the Clinch Mountain area, Virginia and Tennessee, Proj. NR 389-402. Technical report 3. Columbia University. Department of Geology. ONR, New York

Nongkynrih JM, Husain Z (2011) Morphometric analysis of the Manas river basin using earth observation data and Geographical Information System. Int J Geomat Geosci 2:2

Oyatayo KT, Bello I, Ndabula C, Godwill GJ, Ademola SJ (2017) A Comparative analysis of drainage morphometry on hydrologic characteristics of Kereke and Ukoghor Basins on flood vulnerability in Makurdi Town, Nigeria. Hydrology 5(3):32-40. https ://doi.org/10.11648/j.hyd.20170503.11

Pallard B, Castellarin A, Montanari A (2009) A look at the links between drainage density and flood statistics. Hydrol Earth Syst Sci 13:1019-1029

Paul II, Bayode EN (2012) Watershed characteristics and their implication for hydrologic response in the Upper Sokoto Basin Nigeria. J Geogr Geol 4(2):147-155

Petersen JM, Sack D, Gabler RE (2017) Physical geography. CENGAGE Learning, Boston

Rai PK, Mohan K, Mishra S, Ahmad A, Mishra VN (2014) A GISbased approach in drainage morphometric analysis of Kanhar River Basin, India. Appl Water Sci 7:217-232. https://doi. org/10.1007/s13201-014-0238-y

Raj R, Maurya DM, Chamyal LS (1999) Evolution of Mahi drainage basin during quaternary: a morphometric approach, Gondwana. Geol Mag Spl 4:131-139

Rao NS (2016) Hydrogeology: problems with solutions. PHI Private Limited, New Delhi

Ritter DF, Kochel RC, Miller JR (1995) Process geomorphology. WCB/McGraw-Hill, New York. Retrieved at https://www.wou. edu/las/physci/taylor/geog522/rittchp5.pdf.

Sarp G, Toprak V, Duzgun S (2011) Hypsometric properties of the hydraulic basins located on Western part of Nafz. In: 34th International symposium on remote sensing of environment theme: water a limited and degraded resource, Sydney, Australia

Schumn SA (1956) Evolution of drainage systems and slopes in Badlands at Perth Amboy. New Jersey. Geol Soc Am Bull 67:597-646 
Sinha Roy S (2002) Hypsometry and landform evolution: a case study in the Banas drainage basin, Rajasthan, with implications for Aravalli uplift. J Geol Soc India 60:7-26

Srinivasan V, Thompson S, Madhyastha K, Penny G, Jeremiah K, Lele S (2015) Why is the Arkavathy river drying? A multiplehypothesis approach in a data-scarce region. Hydrol Earth Syst Sci 19:1905-1917

Strahler AN (1964) Quantitative geomorphology of drainage basins and channel networks. In: Handbook of applied hydrology. McGraw-Hill, New York, pp 439-476

Sujatha ER, Selvakumar R, Rakasimman UAB, Victor RG (2013) Morphometric analysis of sub-watershed in parts of Western Ghats, South India using ASTER DEM. J Geomat Nat Hazards Risk 6:4. https://doi.org/10.1080/19475705.2013.845114

Sukristiyanti S, Maria R, Lestiana H (2018) Watershed-based morphometric analysis: a review. IOP Conf Ser Earth Environ Sci 118:012028. https://doi.org/10.1088/1755-1315/118/1/012028
Suresh TS (2001) An urban water scenario: a case study of the Bangalore metropolis, Karnataka, India. In: Proceedings of symposium. Sixth IAHS Scientific Assembly. Maastricht, The Netherlands.

Vivoni ER, Benedetto FD, Grimaldi S, Eltahir EAB (2008) Hypsometric control on surface and subsurface run-off. Water Resour Res 44:W12502. https://doi.org/10.1029/2008WR006931

Waikar ML, Nilawar AP (2014) Morphometric analysis of a drainage basin using geographical information system: a case study. Int J Multidiscip Curr Res 2:179-184

Willgoose G, Hancock G (1998) Revisiting the hypsometric curve as an indicator of form and process in transport-limited catchments. Earth Surf Process Landf 23:611-623

Yangchan J, Tiwari AK, Sood A (2015) Morphometric analysis of drainage basin through gis: a case study of sukhna lake watershed in lower Shiwalik, India. Int J Sci Eng Res 6(2):1015-1023 